\title{
The case for replicable structured full proportionality analysis in all cases concerning fundamental rights
}

\author{
Adam Ramshaw \\ Northumbria Law School, Northumbria University, Newcastle upon Tyne, UK \\ *Author email: a.ramshaw@northumbria.ac.uk
}

(Accepted 3 November 2017)

\begin{abstract}
Proportionality has been testing the judiciary for decades. However, a single replicable model of proportionality has not been consistently applied by the courts. This paper explores the differential application of proportionality in English law. It is argued that these differential approaches create doctrinal confusion and give rise to numerous shortcomings. These shortcomings include: (i) the a priori weighting of fundamental rights; (ii) undue deference to state institutions; and (iii) variable judicial scrutiny dependent upon the source of the rights in question. It will be argued here that the courts ought to adopt a common standard of proportionality review in all proceedings concerning fundamental rights. The viability of this approach will then be tested against existing case law.
\end{abstract}

Keywords: proportionality; human rights; fundamental rights

\section{Introduction}

The domestic judiciary first gave guidance on the structure of proportionality in De Freitas. ${ }^{1}$ The Privy Council in De Freitas, drawing upon judgments from elsewhere in the Commonwealth, found that proportionality required a three-limbed analysis of the infringement in question. This test has since been reconsidered by the House of Lords on numerous occasions, eventually leading to the development of a four-limb proportionality test where the Human Rights Act 1998 (HRA 1998) is pleaded. ${ }^{2}$ Therefore, in assessing whether a measure infringing fundamental rights is proportionate the court must ask whether:

1. the legislative objective was sufficiently important to justify limiting a fundamental right;

2. the measures designed to meet the legislative objective were rationally connected to it;

3. the means used to impair the right or freedom were no more than is necessary to accomplish the objective; and

4. the measure strikes a fair balance between the rights of the individual and the interests of the community. ${ }^{3}$

It might, therefore, be thought that the proportionality analysis to be conducted by the courts is straightforward, particularly in those cases where fundamental rights are pleaded. However, a line

\footnotetext{
${ }^{1}$ De Freitas $v$ Permanent Secretary of Ministry of Agriculture, Fisheries, Lands and Housing [1999] 1 AC 69 (PC).

${ }^{2} R v$ Oakes [1986] 1 SCR 103; $R$ (Razgar) $v$ Secretary of State for the Home Department [2003] EWCA Civ 840, [2003] INLR 543; Huang $v$ Secretary of State for the Home Department [2007] UKHL 11, [2007] 2 AC 167.

${ }^{3}$ Bank Mellat v HM Treasury (No 2) [2013] UKSC 39, [2014] AC 700 at [20].

(c) The Society of Legal Scholars 2018. This is an Open Access article, distributed under the terms of the Creative Commons Attribution licence (http://creativecommons.org/licenses/by/4.0/), which permits unrestricted re-use, distribution, and reproduction in any medium, provided the original work is properly cited.
} 
of recent judgments from the Supreme Court demonstrates that the application of proportionality and proportionality's precise contours are as muddied as ever, with numerous conceptions of proportionality being applied contemporaneously.

This paper considers each of these conceptions and highlights the shortcomings of disparate approaches to proportionality specifically in those cases where fundamental rights are at issue. The paper proceeds in the following order. Section 1 analyses the emergence of proportionality in English law and its subsequent development. Sections 2-4 discuss the disparate conceptions of proportionality which have arisen in English law. Section 5 then looks to explain the emergence of these models but questions their continued probity. The failings of these differential approaches are outlined in section 6, alongside the problems which have arisen as a result of doctrinal confusion within the courts. The merits of a single replicable model of proportionality will then be demonstrated in section 7, where 'full proportionality analysis' is applied to Manchester City Council v Pinnock, Akerman-Livingstone $v$ Aster Communities Ltd ${ }^{5}$ and $R$ (Lumsdon) $v$ Legal Services Board. ${ }^{6}$ The argument here is that full proportionality analysis provides an improved approach to litigation concerning fundamental rights. What full proportionality analysis offers over the current approach of the court is an 'argumentative structure ${ }^{77}$ which takes account of the disparate interests in play where fundamental rights are pleaded whilst giving appropriate weight to such rights and the context of the case.

\section{Proportionality, a tree with many branches?}

Proportionality 'has taken on a distinctly protean nature. ${ }^{8}$ Within this protean principle Bjorge and Williams have identified up to six competing approaches to proportionality: ${ }^{9}$

1. 'normal' two-stage EU proportionality; ${ }^{10}$

2. 'normal' three-stage EU proportionality; ${ }^{11}$

3. EU manifest disproportionality; ${ }^{12}$

4. 'normal' four-stage ECHR proportionality; ${ }^{13}$

5. ECHR manifestly without reasonable foundation proportionality; ${ }^{14}$ and

6. proportionality at common law. ${ }^{15}$

On its face this six-fold understanding of proportionality is a fair reflection of proportionality's manifestations. However, Bjorge and Williams's six-fold model is capable of simplification, a virtue yearned for in this area of doctrinal confusion. ${ }^{16}$ It is submitted here that whilst it is possible to point to examples of Bjorge and Williams's analysis, what the six-fold approach does is identify the historical development of proportionality in its various arenas. There are broader groupings visible in contemporary proportionality jurisprudence, namely:

\footnotetext{
${ }^{4}$ Manchester City Council v Pinnock [2010] UKSC 45, [2011] 2 AC 104.

${ }^{5}$ Akerman-Livingstone $v$ Aster Communities Ltd (formerly Flourish Homes Ltd) [2015] UKSC 15, [2015] AC 1399.

${ }^{6} R$ (Lumsdon) v Legal Services Board [2015] UKSC 41, [2016] AC 697.

${ }^{7}$ J Rivers 'The presumption of proportionality' (2014) 77 MLR 409 at 409.

${ }^{8} \mathrm{E}$ Bjorge and JR Williams 'The protean principle of proportionality: how different is proportionality in EU contexts?' (2016) 75 Cambridge Law Journal 186 at 188.

${ }^{9}$ Ibid.

${ }^{10}$ Case 11/70 Internationale Handelsgesellschaft mbH $v$ Einfuhr und Vorratsstelle für Gertreide und Futtermittel [1970] ECR 1125 .

${ }^{11} \mathrm{C}-453 / 03 R$ (on the application of ABNA Ltd) $v$ Secretary of State for Health [2005] ECR I-10423.

${ }^{12} \mathrm{C}-331 / 88$ R $v$ Minister of Agriculture, Fisheries and Food and Secretary of State for Health, ex $p$ Fedesa [1990] ECR I-4023.

${ }^{13}$ Bank Mellat, above n 3.

${ }^{14}$ British Gurkha Welfare Society v United Kingdom (2017) 64 EHRR 11.

${ }^{15}$ De Freitas, above n 1.

${ }^{16}$ Bjorge and Williams, above n 8, at 188 .
} 
1. flexible unstructured proportionality (by simply asking whether the measure is a proportionate means of achieving a legitimate aim); ${ }^{17}$

2. structured proportionality where EU rights apply; and

3. structured proportionality where HRA 1998 rights apply. ${ }^{18}$

For instance, in the case of both two and three-stage EU proportionality it would appear that the EU courts are in fact always applying three-stage proportionality, albeit on some occasions more overtly than others. ${ }^{19}$ In the third stage the court will balance the competing interests pleaded. ${ }^{20}$ Where this structure is engaged a fourth stage (frontloaded into proportionality analysis) is never far away; where the court is asking if a measure is suitable and necessary there has already been an implicit acknowledgment that the end is a legitimate aim.

In the case of 'ECHR manifestly without reasonable foundation proportionality' Bjorge and Williams have mistaken the phraseology of the European Court of Human Rights for a model of proportionality in itself. A review of the Strasbourg Court's utilisation of the 'manifestly without reasonable foundation' test demonstrates that rather than applying a different proportionality test the court sees a decision manifestly without reasonable foundation as a trigger for proportionality analysis. ${ }^{21}$ Where a decision is made that is manifestly without reasonable foundation then the Strasbourg court will apply proportionality in its four stages. ${ }^{22}$ Lastly, Bjorge and Williams refer to 'proportionality at common law' without reference to the instances in which the domestic courts have deployed proportionality in relation to the common law. It is unquestionable that the courts have adopted proportionality where HRA rights and EU rights are in play, however, proportionality as a general head of judicial review is a comparatively recent development in administrative law. ${ }^{23}$ In those cases where proportionality will be called upon within the common law then it would appear that the four-stage structure of proportionality referred to at the beginning of this paper is open to the courts where fundamental rights are concerned. ${ }^{24}$

De Freitas provides an example of the courts' approach to proportionality in the context of fundamental rights, with the Privy Council applying a three-stage proportionality assessment testing the importance of the legislative objective, the objective's rational connection to the objective, and the necessity of the measure itself. De Freitas concerned the constitutional rights afforded by the constitution of Antigua and Bermuda. De Freitas therefore might strictly fall outside of the categories outlined by Bjorge and Williams but it may be that the case rested on what, in domestic law, would be termed Convention rights protected by the HRA 1998 or perhaps even 'proportionality at common law', ${ }^{25}$ proportionality at common law being the test which has slowly influenced areas of law lying beyond EU or Convention bases. ${ }^{26}$ Yet, since De Freitas the courts have persistently reassessed the nature of proportionality and the circumstances in which it will be applied.

Following such reassessments the courts' reliance upon De Freitas three-stage proportionality has not held sway with judicial concerns over the lack of a balancing exercise. ${ }^{27}$ The adoption of a

\footnotetext{
${ }^{17}$ Manchester City Council v Pinnock, above n 4.

${ }^{18}$ These approaches are discussed in detail below.

${ }^{19}$ P Craig EU Administrative Law (Oxford: Oxford University Press, 2012) pp 591-592.

${ }^{20}$ Ibid, ch 19.

${ }^{21}$ Connors $v$ United Kingdom (2005) 40 EHRR 9; Stec v United Kingdom (2006) 43 EHRR 47; Carson v United Kingdom (2010) 51 EHRR 13; British Gurkha Welfare Society, above n 14.

${ }^{22}$ British Gurkha Welfare Society, above n 14.

${ }^{23} \mathrm{Y}$ Nehushtan 'The non-identical twins in UK public law: reasonableness and proportionality' (2017) 50 Israel Law Review 69 at $85-86$.

${ }^{24}$ Kennedy v Charity Commission [2014] UKSC 20, [2014] 2 WLR 808 at [54]; Pham v Secretary of State for the Home Department [2015] UKSC 19, [2015] 1 WLR 1591 at [95].

${ }^{25}$ Bjorge and Williams, above $\mathrm{n} 8$.

${ }^{26}$ See for example Pham, above n 24, at [105].

${ }^{27} R$ (Razgar) $v$ Secretary of State for the Home Department, above $\mathrm{n}$ 2, at [20]; Huang $v$ Secretary of State for the Home Department, above n 2.
} 
four-stage proportionality test should then be welcomed and now appears to be accepted following Bank Mellat v HM Treasury. ${ }^{28}$

In Bank Mellat the proportionality of the measure turned on the question as to whether a less intrusive measure could have been implemented and whether the measure was proportionate and rationally connected to the aim sought. The case concerned measures taken by the UK government against Bank Mellat, an Iranian bank, as a result of international sanctions placed upon Iran. The source of these sanctions was the Financial Restrictions (Iran) Order 2009, SI 2009/2725 enacted by the Treasury. In assessing the proportionality of these regulations the Supreme Court applied four-stage proportionality. In so doing the court found that the measure to be disproportionate as it unduly targeted Bank Mellat over other Iranian banks thereby making the measure irrational, arbitrary and unnecessary.

Despite the apparent clarity with which the Supreme Court spoke of proportionality in Bank Mellat the contours of proportionality still appear to be, in some instances, differential. ${ }^{29}$ This is particularly evident in a string of recent cases from the Supreme Court, each of which employs different versions of proportionality: flexible unstructured proportionality; structured proportionality where EU rights apply; and structured proportionality where HRA rights apply. Each of these approaches is mutually exclusive and, as will be discussed below, makes the form of proportionality dependent upon the facts of the case before the court and the source of the rights claimed. It is accepted that the proportionality model advocated in this paper will not always lead to markedly different outcomes to those reached by the court under current case law. However, the stakes in any assessment of proportionality must be borne in mind when reviewing the current approaches adopted by the courts. If it is accepted that the rights contained in the Convention and other human rights instruments which have a bearing on domestic law, such as the European Charter on Fundamental Freedoms, may be termed fundamental then the courts' approach to these rights ought to be consistent and predictable in order for these rights to be as effectual as possible. ${ }^{30}$ Proportionality is, after all, intended to be a 'structured approach to balancing fundamental rights with other rights and interests in the best possible way'. ${ }^{31}$ In practical terms the failings of multiple proportionality tests have resulted in certain interferences facing variable scrutiny. The idea of variable scrutiny is not novel in administrative law. ${ }^{32}$ However, in the context of fundamental rights the method by which courts measure interference should be consistently intensive. ${ }^{33}$ Where proportionality is applied in an inconsistent fashion, fundamental rights may receive little appreciation. Litigants and counsel are left to 'take an educated guess at whether a court would regard ${ }^{34}$ a measure as proportionate. In such a case it is an individual's interest which most likely injured, as the state's reasoning weighs heavily in the court's mind. ${ }^{35}$

\section{Flexible unstructured proportionality}

Flexible unstructured proportionality asks whether the measure is 'a proportionate means of achieving a legitimate aim'. ${ }^{36}$ Those cases utilising flexible unstructured proportionality tend to concern sensitive political issues such as national defence or resource (re)allocation to which the courts have

\footnotetext{
${ }^{28}$ Bank Mellat, above n 3.

${ }^{29}$ See generally A Davies and J Williams 'Proportionality in English law' in S Ranchordás and B de Waard (eds) The Judge and the Proportionate Use of Discretion: a Comparative Study (Routledge, 2016).

${ }^{30} R(N) v$ Lewisham LBC [2014] UKSC 62, [2014] 3 WLR 1548 at [62]; $R$ (H) v Secretary of State for Health [2005] UKHL 60, [2006] 1 AC 441.

${ }^{31} J$ Rivers 'Proportionality and variable intensity of review' (2006) 65 Cambridge Law Journal 174 at 176.

${ }^{32}$ See generally Associated Provincial Picture Houses Ltd $v$ Wednesbury Corpn [1948] 1 KB 223; O'Reilly v Mackman [1983] 2 AC 237; M Taggart 'Proportionality, deference, Wednesbury' (2008) New Zealand Law Review 423.

${ }^{33} \mathrm{E}$ Brems and L Lavrysen, "Don't use a sledgehammer to crack a nut": less restrictive means in the case law of the European Court of Human Rights' (2015) 15 Human Rights Law Review 139 at 145-146.

${ }^{34} \mathrm{~T}$ Hickman 'The substance and structure of proportionality' (2008) PL 694 at 716.

${ }^{35} R$ (Nadarajah) $v$ Secretary of State for the Home Department [2005] EWCA Civ 1363; Hickman, above n 34.

${ }^{36}$ Manchester City Council v Pinnock, above n 4, at [52].
} 
traditionally afforded deference to the enactments of Parliament or the decisions of ministers. ${ }^{37}$ Where deference is exercised by the courts it is clear that the courts consider the matter of proportionality, particularly the balancing of rights, to have been pre-emptively secured by Parliament due to their 'institutional competence' over the courts. ${ }^{38}$ The assumption here is that Parliament has conducted an inclusive debate addressing relevant issues including those of human rights. ${ }^{39}$ However, while it may be notionally true that a cross section of representations will be raised in Parliament, this does not necessarily amount to balanced legislation that respects fundamental rights. For instance, the courts have revisited settled points of law following the enactment of the HRA $1998^{40}$ but equally there are instances where there is a prima facie assumption that the appropriate balance is innate in the relevant legislation. ${ }^{41}$ Beyond the inconsistency of this, if it is assumed that legislation or infringing acts are proportionate, then the reasons proffered for the HRA 1998's introduction are undermined. In other words, if statutes are already sufficiently sensitive to the applicable competing interests of particular proceedings then there seems little point in 'bringing rights home'. ${ }^{42}$

Flexible unstructured proportionality is visible in cases concerning the vindication of property rights. This has been most apparent where the right to respect for one's home is pleaded in the context of Art 8 of the Convention. In this area the courts have neglected the contours of proportionality in favour of flexibility and assumptions of proportionality. ${ }^{43}$ In such cases there is a dereliction of duty on the part of the court to rigorously test the proportionality of a given measure in the face of Convention rights. In such cases the overarching caution in the courts is caused by two factors: (i) reverence for private property alongside the certainty typically attached to such rights; ${ }^{44}$ and (ii) the institutional deference owed to Parliament or the executive.

This flexible unstructured approach to proportionality is synonymous with a 'managerial' tact towards balancing conflicting rights, which in turn limits the force of Convention rights. ${ }^{45}$ This is in light of the scarce resources available to public authorities with the courts deferring to public authorities as to how these resources should be best used. It is of course understandable that English courts would be cautious about imposing a positive duty on a party who otherwise has an absolute legal power on a prima facie reading of statute. ${ }^{46}$ This is particularly the case where Parliament and the courts have constructed a complicated framework to manage the competing interests of those involved in proceedings concerning property. ${ }^{47}$ In so doing those individuals looking to rely on the HRA 1998 are marginalised by the use of flexible unstructured proportionality.

Manchester City Council $v$ Pinnock ${ }^{48}$ demonstrates a general tendency of English courts to avoid the language of balancing in their judgments. ${ }^{49} \mathrm{Mr}$ Pinnock was a local authority tenant who argued that in his circumstances it would be disproportionate for the court to make a possession order. This

\footnotetext{
${ }^{37} R v$ DPP ex p Kebilene [2000] 2 AC 326 at 381.

${ }^{38}$ J Jowell 'Judicial deference: servility, civility or institutional capacity?' (2003) PL 592.

${ }^{39}$ A Kavanagh 'Proportionality and parliamentary debates: exploring some forbidden territory' (2014) 34 Oxford Journal of Legal Studies 443 at 472.

${ }^{40}$ Campbell v Mirror Group Newspapers Ltd [2004] UKHL 22, [2004] 2 AC 457.

${ }^{41}$ Hounslow LBC v Powell [2011] UKSC 8, [2011] 2 AC 186.

${ }^{42}$ Home Office, Rights Brought Home: The Human Rights Bill (Cm 3782, 1997).

${ }^{43}$ McDonald v McDonald [2016] UKSC 28, [2016] 3 WLR 45 at [40]-[47]; Barca v Mears [2004] EWHC 2170 (Ch), [2005] 2 FLR 1; Donohoe v Ingram [2006] EWHC 282 (Ch), [2006] 2 FLR 1084; Official Receiver for Northern Ireland v Rooney [2008] NICh 22, [2009] 2 FLR 1437.

${ }^{44}$ L Fox O’Mahony 'Property outsiders and the hidden politics of doctrinalism' (2014) 67 Current Legal Problems 409 at 411 .

${ }^{45} \mathrm{~A}$ Latham 'Talking without speaking, hearing without listening? Evictions, the law lords and the European Court of Human Rights' (2011) PL 730; O Saunders 'Article 8 in housing law: no home for human rights values' (2016) 6 Southampton Student Law Review 72.

${ }^{46}$ Kay v Lambeth LBC [2006] UKHL 10, [2006] 2 AC 465 at [92].

${ }^{47}$ As to this complicated framework see N Madge 'Time to clear the forest' (The Times, 25 July 2000), available at www. nicmadge.co.uk/housing_law_reform.php (accessed 26 August 2018).

${ }^{48}$ Manchester City Council v Pinnock, above n 4.

${ }^{49}$ Rivers, above n 31, at 179.
} 
argument implied that it must be open to a court to assess the proportionality of a possession order. In assessing this the Supreme Court found that Art 8 of the Convention (and the HRA 1998, ss 2-3) allowed for courts to consider the proportionality of an order notwithstanding the mandatory language of statute. However, for Mr Pinnock this did little to assist, as the court found a possession order to be proportionate. Beyond the affirmation that proportionality had some role to play in the proceedings there is little guidance in the judgment to suggest how courts might assess proportionality over simply asking whether the measure is a proportionate means of achieving a legitimate aim. ${ }^{50} \mathrm{In}$ assessing this the court placed great weight on the authority's 'unencumbered property rights' and its obligation to efficiently manage its housing stock. ${ }^{51}$ The failure to conceive a structured approach to proportionality in possession cases has continued following Pinnock. ${ }^{52}$ These failings demonstrate the tendency of English courts to opt for certainty and deference over doctrinal consistency.

It is clear from the above that the courts are sensitive to the democratic and institutional credentials of the party purportedly infringing fundamental rights. However, it is not only cases concerning institutional deference or property rights which have attracted flexible unstructured proportionality. The approach is also visible in areas of policy reserved to the executive, for example admission to the UK. In such cases despite the court appreciating a structured approach to proportionality, the court has turned its mind to the weight to be placed on the values at stake. ${ }^{53}$ This exercise is carried out independent of any analysis of proportionality and therefore fails to sufficiently engage with proportionality. Where proportionality is not robustly applied either in cases concerning private property rights or where deference is the key concern in the court's mind, the court is found applying a test startlingly similar to traditional judicial review over a penetrating proportionality analysis. ${ }^{54}$

\section{Structured proportionality where EU rights apply}

Where the court applies flexible unstructured proportionality extra-legal considerations weigh upon judicial minds. However, there are instances where the courts have heard arguments regarding fundamental rights in other contexts where the courts have been willing to apply structured proportionality. In so doing, the infringing action is exposed to penetrating analysis. This disparity is concerning in itself due to the potential for differential results from different legal tests. ${ }^{55}$ This is attenuated where it is apparent that the cause for this differentiation is the legal source from which the rights in question flow. Here those sources are EU law and the HRA 1998. However, this misunderstands the nature of rights protection in domestic law and the jurisprudence of the courts in these supranational jurisdictions. A review of this approach draws out a common theme; the domestic courts are favouring the views of these supranational courts to varying degrees, making proportionality an abstract coloured by the legal instruments in its penumbra.

The Supreme Court in Bank Mellat held that four-stage proportionality will be applicable where fundamental rights are pleaded with no apparent concern paid to their source. The closest the court comes to acknowledging the source of rights is Lord Reed's recognition that proportionality is applied in a rather broad brush fashion by the European Court of Human Rights and with variable intensity in the Court of Justice of the European Union. ${ }^{56}$ However, the stages of proportionality are

\footnotetext{
${ }^{50}$ Manchester City Council v Pinnock, above n 4.

${ }^{51}$ Ibid at para 54. See also A Goymour 'Possession proceedings and human rights - the final word?' (2011) 70 Cambridge Law Journal 9 at 10-11.

${ }^{52}$ Corby BC $v$ Scott [2012] EWCA Civ 276, [2013] PTSR 141; Thurrock $v$ West [2012] EWCA Civ 1435, [2013] HLR 5; McDonald v McDonald [2014] EWCA Civ 1049, [2015] Ch 357. See also AXA General Insurance Ltd v HM Advocate [2011] UKSC 46, [2012] 1 AC 868.

${ }^{53} R$ (Lord Carlile of Berriew) $v$ Secretary of State for the Home Department [2014] UKSC 60, [2015] AC 945 at [39]-[52].

${ }^{54}$ On the distinction between traditional judicial review and proportionality see Connors, above n 21; Lord Carlile of Berriew, above n 53, at [69].

${ }^{55} \mathrm{TJ}$ Gunn 'Deconstructing proportionality in limitations analysis' (2005) 19 Emory International Law Review 465.

${ }^{56}$ Bank Mellat, above n 3, at [68]-[69].
} 
visible in each court and moreover there are legitimate reasons for this difference in approach due to the varying institutional capacities of each court. ${ }^{57}$ Yet, in Akerman-Livingstone $v$ Aster Communities $L t d^{58}$ the Supreme Court found that four-stage structured proportionality will be applicable where rights sourced from EU law are pleaded, whereas those rights flowing from the Convention may use a truncated version of proportionality.

Akerman concerned a local authority seeking recovery of a property let to a tenant who suffered from a mental disorder which amounted to a disability for the purposes of the Equality Act $2010 .^{59}$ The tenant was housed in temporary accommodation by the local authority in the exercise of its homelessness duties. Whilst occupying this temporary accommodation over a period of nine months the local authority offered the tenant numerous permanent tenancies. However, the tenant declined all of these offers on the basis that the locations were detrimental to his mental health. The local authority therefore sought to recover possession of the temporary accommodation. This was resisted by the tenant on the basis that he had been discriminated against due to his disability and that it would be disproportionate to dispossess him due to s 15 of the Equality Act 2010 and Art 8 of the Convention respectively. He argued that the protection afforded by s 15 required a higher standard than that required by Art 8 as understood following Pinnock, namely structured four-stage proportionality. $^{60}$

The Equality Act 2010 allows for discrimination where the measure is 'a proportionate means of achieving a legitimate aim'. ${ }^{61}$ This wording is not identical to Art 8 of the Convention but the two passages 'have come to be interpreted in the same way'. ${ }^{62}$ The primary reason given for a differential approach to proportionality by the Supreme Court was the consolidating nature of the Equality Act 2010 which apparently seeks to bring together EU law. ${ }^{63}$ Whilst it is true that many of the provisions incorporated in the 2010 Act are the product of the EU there are also purely domestic creations which have been included. ${ }^{64}$ Therefore, considering the Equality Act 2010 as the domestic manifestation of EU law over-simplifies matters.

In justifying the existence of two proportionality tests, Baroness Hale noted that the 'first and most obvious difference ${ }^{35}$ was that Equality Act 2010 applied to both public and private actors unlike Art 8 which is applicable only to public authorities. Therefore, the freedom from discrimination created by the Equality Act 2010 exists in addition to Art 8 and requires discriminatory measures to be tested against four-stage structured proportionality in the following guise:

1. is the objective sufficiently important to justify limiting a fundamental right?

2. is the measure rationally connected to the objective?

3. are the means chosen no more than is necessary to accomplish the objective?

4. is the impact of the rights infringement disproportionate to the likely benefit of the impugned measure?

This conceputalisation of proportionality will be referred to as 'full proportionality analysis ${ }^{66}$ for the remainder of this paper. The reasons given by Baroness Hale for this distinction rest upon

\footnotetext{
${ }^{57}$ See sections 6 and 7 below for discussion on this.

${ }^{58}$ Akerman-Livingstone $v$ Aster Communities Ltd, above $\mathrm{n} 5$.

${ }^{59}$ Equality Act 2010, ss 4 and 6; Akerman-Livingstone v Aster Communities Ltd, above n 5, at [2].

${ }^{60}$ Akerman-Livingstone $v$ Aster Communities Ltd, above n 5, at 1402-1403.

${ }^{61}$ See for example Equality Act 2010, ss 13(2), 15(1)(b).

${ }^{62}$ Akerman-Livingstone $v$ Aster Communities Ltd, above $\mathrm{n}$, at [27].

${ }^{63}$ Ibid, at [28].

${ }^{64}$ Take for example the Equal Pay Act 1970 and the Sex Discrimination Act 1975.

${ }^{65}$ Akerman-Livingstone $v$ Aster Communities Ltd, above $\mathrm{n}$, at [23].

${ }^{66} \mathrm{C}$ Chan 'Proportionality and invariable baseline intensity of review' (2013) 33 Legal Studies 1 at 8-11, although it is appreciated that Chan uses this term in a different context.
} 
Parliament's decision to enact the Equality Act 2010 to free people from discrimination. ${ }^{67}$ The difficulty with this view is the overlap with Art 14 of the Convention, which similarly seeks to ensure the equal application of human rights rather than a prohibition of discrimination generally. ${ }^{68}$ Nevertheless, in assessing measures which may offend Art 14 the European Court of Human Rights has adopted full proportionality analysis. ${ }^{69}$ On this basis it would appear that there is scope in this area for domestic and Strasbourg views on proportionality to dovetail as each is adopting fourstage structured proportionality in keeping with the developments of the common law. ${ }^{70}$ This is particularly the case in light of the common law's apparent preference for four-stage proportionality. ${ }^{71}$ This is evident firstly in the emergence of three-pronged proportionality in De Freitas and the resultant recognition of the fourth stage - balancing. ${ }^{72}$ Article 14 does not appear to have been argued by counsel in Akerman and so there is no commentary by the Justices on Art 14's potential effects alongside the Equality Act 2010. However, it would seem paradoxical to suggest that domestic legislation which has in effect adopted a standard from the European Court of Human Rights ought to be more potent than the same test as applied to Convention rights contained in Sch 1 to the HRA 1998.

The approach in Akerman is all the more concerning in that it allows for public and private actors to be held to a higher standard (under the Equality Act 2010) than solely public actors (when considering the protection of HRA 1998 rights). There is no comment made here as to the appropriateness of full proportionality analysis in horizontal proceedings, nor is the argument made here that full proportionality analysis ought to be adopted in instances not concerning the state, although it is recognised by the author that there are relationships outside those involving the state which may be hugely distressing to individuals. ${ }^{73}$ It should be remembered that the aims of the Equality Act 2010 are not reflected in the Convention or the HRA 1998 as such. The closest the Convention comes to prohibiting discrimination is Art 14. The Convention framework is edging towards a general prohibition of discrimination in Protocol 12 which relates to 'the enjoyment of any right set forth by law', yet Protocol 12 has not been ratified by the UK or added to the HRA 1998, Sch 1 and so has no standing in domestic law. It is possible, if politically unlikely, that the UK will ratify Protocol 12 and add the provision to Sch 1 to the HRA 1998 thereby making Protocol 12 justiciable in domestic courts. If this were to occur, courts, under the current practice, would apply structured proportionality to contraventions of the Equality Act 2010, whereas an individual pleading Protocol 12 would be, following Akerman, left with flexible unstructured proportionality. This clearly demonstrates the unsafe doctrinal foundations of the approach in Akerman.

The reason for this change of approach from flexible unstructured proportionality to Akerman appears to be linked to the interests in play in these proceedings. For instance in Pinnock the court was concerned with mandatory legislation, statutory interpretation, and hard-edged proprietary rights, whereas in Akerman the court are utilising a test purportedly built-in to the applicable legislation to

\footnotetext{
${ }^{67}$ See generally Equality Act 2010, ss 5-12.

${ }^{68}$ See also the increased equality provisions of Protocol 12 of the European Convention on Human Rights, which the UK is yet to ratify.

${ }^{69}$ Belgian Linguistic Case (1979-80) 1 EHRR 252; DH v Czech Republic (2008) 47 EHRR 3; Bah v United Kingdom (2012) 54 EHRR 21.

${ }^{70}$ Bank Mellat, above n 3, at [72].

${ }^{71}$ Huang $v$ Secretary of State for the Home Department, above n 2; A v Secretary of State for the Home Department [2004] UKHL 56, [2005] 2 AC 68 at [30]-[44]; $R$ (Daly) $v$ Secretary of State for the Home Department [2001] UKHL 26, [2001] 2 AC 532.

${ }^{72}$ See for example A $v$ Secretary of State for the Home Department, above $\mathrm{n} 71$, at [38]; $R v$ DPP ex $p$ Kebilene, above $\mathrm{n} 37$; De Freitas, above n 1.

${ }^{73}[\mathrm{~T}]$ here are other relationships, not only relationships between the individual and government, which can also blight lives, and which for many individuals can result in tragedy. Very serious distress can be caused by an employer, by a landlord, or by a neighbour. Not all wrecked lives are caused by governments': Peter Archer MP, HC Deb, vol 814, cols 1861-1862, 2 April 1971.
} 
quell historic injustices, thereby giving the court more latitude in its findings. ${ }^{74}$ Moreover, the courts have been comfortable finding a breach of Convention rights where that breach has involved Art 14 and notwithstanding the requirements of statute ${ }^{75}$ or the flexibility afforded to ministers. ${ }^{76}$ It is true that in law context is everything. ${ }^{77}$ However, this context should determine the outcome of the test rather than form of the test itself. The disparate approaches demonstrate a reticence in the courts to engage with substantive questions of adjudication. Of course the problems which flow from a recalibration of interests raise difficult jurisprudential questions regarding the reallocation or stymying of rights otherwise thought to be preferential, but this is not a reason to revert to unpredictable legal tests.

\section{Structured proportionality for HRA 1998 rights}

The variability of proportionality tests is disappointing primarily due to the doctrinal confusion created by this approach, particularly for those litigants who appear before the court who must guess the necessary legal hurdles they must clear to prove the (dis)proportionality of a given course of action. The differential approaches of the Supreme Court may easily lead one to the view that the court is applying these tests 'depending on the facts, or on the judge's own view of the merits' of a given case. ${ }^{78}$ In such cases the differential tests which have emerged equally depend upon a particular bench's opinion on the deference, due weight to be accorded to a party's decision, or the legislation in question. In this exercise, the opinions of the Supreme Court Justices regarding the role of the relatively new court in the UK's constitutional framework will no doubt influence judgments. ${ }^{79}$ For instance, Lord Kerr's views of the Supreme Court's ambit are clearly different to those of Lord Sumption, with the former advocating a robust application of proportionality, whilst the latter favours a nuanced approach, taking account of the institutional nature of the decision maker. ${ }^{80}$ The concerns of Lord Sumption are particularly prevalent in those cases concerning national security, and so it might be thought that the courts are more comfortable applying structured review in those cases which are more traditionally understood to be within the sphere of justiciability. $R$ (Lumsdon) $v$ Legal Services Board ${ }^{81}$ is such a case, where structured proportionality has been applied in light of HRA 1998 rights.

Lumsdon followed Akerman by three months and yet Akerman is not cited in any of the Supreme Court Justice opinions - this is in spite of three of the five Justices being the same in each case. Lumsdon concerned the 'Quality Assurance Scheme for Advocates', which sought to increase standards at the criminal bar and required barristers to be assessed by judges before being able to take instructions in certain matters. The scheme was challenged on the basis that it was contrary to EU Directive 2006/123 $3^{82}$ and the Provision of Services Regulations ${ }^{83}$ in that the objective pursued could be achieved by less intrusive means and there was no overriding reason within the public interest for the state to interfere with advocacy training in this instance. In other words the scheme was disproportionate.

In assessing domestic conceptions of proportionality Lord Reed and Lord Toulson, giving judgment on behalf of a unanimous court, found that EU and Strasbourg approaches to proportionality

\footnotetext{
${ }^{74}$ A Baker 'Proportional, not strict, scrutiny: against a US suspect classificiations model under Article 14 ECHR in the UK' (2008) 56 American Journal of Comparative Law 847.

${ }^{75}$ Ghaidan $v$ Godin-Mendoza [2004] UKHL 30, [2004] 2 AC 557.

${ }^{76} \mathrm{~A} v$ Secretary of State for the Home Department, above $\mathrm{n} 71$.

${ }^{77}$ Daly, above n 71 , at [28].

${ }^{78}$ S Lee and J Lee 'Humility in the supreme court' (2015) 26 King's Law Journal 165 at 174.

${ }^{79}$ Ibid, at 174 .

${ }^{80} \mathrm{Ibid}$, at 172-174; Lord Carlile of Berriew, above n 53; Lord Sumption 'Foreign affairs in English courts since 9/11'

(Lecture at the Department of Government, London School of Economics, 14 May 2012).

${ }^{81}$ Lumsdon, above $\mathrm{n} 6$.

${ }^{82}$ Council Directive of 12 December 2006 on Services in the Internal Market [2006] OJ L367/36.

${ }^{83}$ Provision of Services Regulations 2009, SI 2009/2999.
} 
differed. ${ }^{84}$ In matters concerning the Convention and the HRA 1998 four-stage structured proportionality should be applied. ${ }^{85}$ In cases which raise a point of EU law, such as Lumsdon, the court should look to Art 5(4) of the Treaty on European Union to assess the proportionality of a given measure. ${ }^{86}$ In light of this, the Supreme Court warned against 'an excessively schematic approach [when dealing with EU law], since the [CJEU] jurisprudence indicates that the principle of proportionality is flexible in its application'. ${ }^{87}$

Lumsdon has since been followed in $R$ (British American Tobacco UK Ltd) $v$ Secretary of State for Health. ${ }^{88}$ The case concerned restrictions placed upon tobacco advertising in an attempt to improve public health. These restrictions were challenged on a number of grounds, including the proportionality of the measures which were enacted in line with an EU directive allowing for restrictions on 'fundamental freedoms. ${ }^{89}$ The case also concerned Convention rights, making the precise form of proportionality to be applied difficult to discern in light of the differing approaches of the Supreme Court. ${ }^{90}$ In spite of the acknowledgment of a plurality of proportionality tests the court in British American Tobacco found that affirmations of two-stage proportionality in EU jurisprudence would nevertheless lead to four-stage proportionality. ${ }^{91}$ Turning attention to the test to be applied when assessing Convention or HRA 1998 rights revealed much the same test in the opinion of Green J. This realisation further undermines the case for applying differential proportionality tests depending upon the source of the rights in question as indicated in Lumsdon.

The argument in favour of a common understanding of proportionality, as a four-pronged test, receives support from Green J's statement regarding proportionality:

It is not in dispute that such a balancing test [proportionality stricto sensu] does arise under the ECHR... and hence in an EU case where the Charter is at stake or where the ECHR is prayed in aid as a general principle of EU law, it would be inconsistent to refrain from similarly applying this component of the proportionality test. To do otherwise would be to create the risk that a Court would apply two different tests when deciding whether the same fundamental right was breached, even though the tests under EU law and the ECHR were intended to be the same. ${ }^{92}$ (emphasis added)

Herein is the crux of this paper. To apply varying proportionality assessments gives rise to considerable inconsistencies and uncertainties in the law over rights which are of the same fundamental character albeit from different sources. Despite Green J's assertion that the varying tests will achieve the same end, or in the least arrive at the same conception of proportionality, this is not always the case as is demonstrated in sections 6-7 below. Rather than assessing the interference with a particular right in a uniform discernible way, the courts are instead finding themselves beholden to their historical institutional character together with the normative background to particular instruments. It might be argued that these are sufficient justifications for the approach adopted in Lumsdon and Bank Mellat, where the court discerned the form of proportionality via the legislative source of the right pleaded.

\footnotetext{
${ }^{84}$ Lumsdon, above n 6, at [26].

${ }^{85} \mathrm{Ibid}$.

${ }^{86}$ Art 5(4) reads: 'Under the principle of proportionality, the content and form of Union action shall not exceed what is necessary to achieve the objectives of the Treaties'.

${ }^{87}$ Lumsdon, above $\mathrm{n}$ 6, at [26].

${ }^{88} R$ (British American Tobacco UK Ltd) $v$ Secretary of State for Health [2016] EWHC 1169 (Admin), [2016] ETMR 38.

${ }^{89}$ Ibid, at [410].

${ }^{90}$ Ibid, at [426].

${ }^{91}$ Ibid, at [427]-[430].

${ }^{92}$ Ibid, at [680].
} 


\section{Defending multiple approaches to proportionality}

There are a number of explanations offered for contemporaneous approaches to proportionality. These explanations might be broadly categorised within two schools; firstly, the institutional nature and functions of courts, and, secondly, the normative background within which courts operate in certain situations.

\section{(a) Institutional nature and functions}

The institutional nature of a court exercising its powers under s 143D of the Housing Act 1996, as was the case in Pinnock, is to allow for a summary assessment of a landlord's procedural duties. If these procedures have been satisfied then a court must make a possession order. ${ }^{93}$ The force of $\mathrm{s} 143 \mathrm{D}$ is given further strength by the view that in the great majority of cases it would be 'burdensome and futile' to require a local authority to argue an order is proportionate. ${ }^{94}$ Therefore, it will be assumed that a local authority landlord is acting in accordance with its duties including those of a public law nature. ${ }^{95}$ This is perhaps anchored in the belief that a freeholder's 'unencumbered property rights ${ }^{96}$ ought to win out over any competing claim. This reverence for certainty in property relationships might be attributed to the idea that fairness is best achieved through certainty, notwithstanding the unsympathetic rules this creates. ${ }^{97}$

Adopting light-touch proportionality might be aligned with deference to the legislature and executive in what is an area fraught with social policy. In this sense the approach of the courts where Art 8 is pleaded in competition with property rights reveals a strong preference for an owner's exclusive control of their possessions. This reveals a built-in predilection to private property rights in English law in keeping with the history of the common law. ${ }^{98}$

The predilection to private property rights fails to account for the broader literature in this area which recognises that the underpinnings of property may be understood in a range of ways. ${ }^{99}$ Foremost of these understandings in Anglo-American thought is the 'bundle of rights' which an owner enjoys. These rights allow for, among other things, the right to use, the right to exclude, and the right to transfer. ${ }^{100}$ This understanding is based upon a Hohfeldian conception of legal rights ${ }^{101}$ which have in turn been transposed into property discourse. ${ }^{102}$ Understood in this way, property rights have correlative 'no-rights' - therefore whilst an owner will have a right to use his own land, others have the correlative no-right. However, to understand these property rights as absolute and unchallengeable overlooks the various instances in which property interests may be stymied. ${ }^{103} \mathrm{~A}$ recognition of these instances brings to light that 'property is intelligible only as a social construct, as a perfect malleable category wholly at the service of collective goals. ${ }^{104}$ This puts property rights on the same plane as other legal rights, including human rights, which themselves may yield to collective

\footnotetext{
${ }^{93}$ Housing Act 1996, ss 143D-143F.

${ }^{94}$ Manchester City Council v Pinnock, above n 4, at [53].

${ }^{95}$ Ibid.

${ }^{96}$ Ibid, at [54].

${ }^{97}$ J Howell 'The Human Rights Act 1998: land, private citizens, and the common law' (2007) 123 LQR 618 at $633-635$.

${ }^{98}$ Semayne's Case (1604) 5 Coke Rep 91; Entick v Carrington 95 ER 807.

${ }^{99}$ See generally AJ MacLeod 'Bridging the gaps in property theory' (2014) 77 MLR 1009; JE Penner and H Smith (eds) Philosophical Foundations of Property Law (Oxford: Oxford University Press, 2013).

${ }^{100}$ JE Penner 'The "bundle of rights" picture of property' (1996) 43 UCLA Law Review 711 at 712-730.

${ }^{101}$ WN Hohfeld 'Some fundamental legal conceptions as applied in judicial reasoning' (1913-1914) 23 Yale Law Journal 16; WN Hohfeld 'Fundamental legal conceptions as applied in judicial reasoning' (1916-1917) 26 Yale Law Journal 710.

${ }^{102}$ AM Honoré 'Ownership' in AG Guest (ed) Oxford Essays in Jurisprudence (Clarendon Press, 1961); AM Honoré Making Law Bind: Essays, Legal and Philosophical (Clarendon Press, 1987).

${ }^{103}$ See for example Housing and Planning Act 2016, Pt 7; Southport Corporation v Esso Petroleum [1954] 2 QB 182 at $195-$ 203; Hunter v Canary Wharf Ltd [1996] AC 655; Holbeck Hall Hotel Ltd v Scarborough Borough Council [2000] QB 836 at 851-857; European Convention on Human Rights, Art 1 to the First Protocol.

${ }^{104}$ A Brudner 'Editor's introduction' (1993) 6 Canadian Journal of Law and Jurisprudence 183 at 184-185.
} 
goals and places property firmly within the gaze of structured proportionality. So to think of property as monolithic and worthy of a weaker form of review in flexible unstructured proportionality analysis misunderstands the nuances of property theory to the detriment of individuals with conflicting fundamental rights. It is law which gives rise to property rights ${ }^{105}$ and therefore law may stay property interests in much the same way as other important rights are limited; where it is proportionate to do so. To do otherwise ties the courts to historical notions of property which do not account for the multi-layered nature of property in a modern legal context. ${ }^{106}$

Another explanation provided in defence of multiple approaches to proportionality is the institutional history of the courts. Any judicial review of administrative action, whether based upon the infringement of fundamental rights or legality, is based in the common law. In such cases the job of the court is to ensure the executive acts within the law and does not go further than allowed for by Parliament. ${ }^{107}$ This historic view is reminiscent of the initial views of the House of Lords where Art 8 came into conflict with private property. ${ }^{108}$ However, where common law rights are pleaded the courts have, apart from the HRA 1998, sought to introduce increased scrutiny approaching proportionality and arguably more intense than flexible unstructured proportionality. ${ }^{109}$ The incorporation of proportionality continues in the area of legitimate expectations, thereby further undermining a court's institutional nature and functions, serving as a justification for disparate approaches to proportionality. ${ }^{110}$

\section{(b) Normative background}

In addition to the institutional justifications for disparate approaches to proportionality, there are also differing normative backgrounds for the rights in question. For instance, the basis and force of rights sourced from EU law differ from those in the HRA 1998. Whilst EU law, in the form of treaties and regulations, is directly applicable in English law, the HRA 1998 rights are given effect by the 1998 Act itself. ${ }^{111}$ In interpreting the nature of HRA 1998 rights the judiciary must of course consider the judgments of the European Court of Human Rights, ${ }^{112}$ however, they are not bound by those judgments in the same way they are CJEU judgments. ${ }^{113}$ Therefore, whilst proportionality may be a common label, there are perhaps legitimate reasons for cultivating differential proportionality tests.

For domestic courts the public/private divide appears to allow for varying conceptions of proportionality, particularly in those cases concerning flexible unstructured proportionality. ${ }^{114}$ In keeping with the institutional trappings of the domestic courts discussed above, the core of private law is often seen to be the vindication of property rights. ${ }^{115}$ Within this conception of private is the idea that the state in such instances '.. . could be regarded as a neutral authority to balance conflicting interests of two parties to find solutions for conflicts that are regarded as purely private'. ${ }^{16}$ This is a drastically different view to that of the courts where fundamental rights, a manifestation of public law, are in play. In such cases the relationship at issue is the relationship between the state and an individual,

\footnotetext{
${ }^{105}$ JO Grunebaum Private Ownership (Routledge \& Kegan Paul, 1987) p 86.

${ }^{106}$ MacLeod, above n 99, at 1014; J Waldron 'To bestow stability upon possession: Hume's alternative to Locke' in Penner and Smith, above $\mathrm{n} 99$.

${ }^{107}$ Davies and Williams, above n 29, p 75

${ }^{108}$ Kay $v$ Lambeth $L B C$, above n 46.

${ }^{109}$ Davies and Williams, above n $29, \mathrm{p} 80$.

${ }^{110}$ See for example ibid.

${ }^{111} R$ (Minton Morrill Solicitors) $v$ The Lord Chancellor [2017] EWHC 612 (Admin).

${ }^{112}$ HRA 1998, s 2.

${ }^{113}$ R Clayton 'Smoke and mirrors: the Human Rights Act and the tmpact of Strasbourg case law' (2012) PL 639.

${ }^{114}$ Hounslow LBC $v$ Powell, above n 41; Lawal v Circle 33 Housing Trust [2014] EWCA Civ 1514, [2015] HLR 9; McDonald $v$ McDonald, above $\mathrm{n} 43$. See also S Nield 'Shutting the door on horizontal effect: McDonald v McDonald' (2017) Conv 148.

${ }^{115}$ J Locke The Second Treatise of Civil Government (Project Gutenberg edn, 1690) ch 3.

${ }^{116} \mathrm{~N}$ Jansen and R Michaels 'Private law and the state: comparative perceptions and historical observations' (2007) 2 Rabels Zeitschrift Für Ausländisches und Internationales Privatrecht 345 at 348.
} 
rather than between individuals. ${ }^{117}$ This divide is then maintained in the HRA 1998. ${ }^{118}$ Alongside this is the influence of the HRA 1998, s 3, which requires courts, so far as is possible to do so, to interpret legislation in a Convention-compliant manner. This is starkly different to the duty imposed upon the courts by the European Communities Act 1972, s 2, which requires domestic courts to recognise the supremacy of EU law irrespective of its incompatibility with UK legislation. ${ }^{119}$ Therefore in such a case the tests which are applied to alleged infringements with rights from an EU source might be expected to face a more robust scrutiny than Convention rights as incorporated by the HRA 1998. However, this is not the track that has been followed by the courts as discussed above in relation to Bank Mellat, Lumsdon, and Akerman.

It is certainly true that it is open to the courts and Parliament to provide for greater protection of rights than is required by the European Court of Human Rights. ${ }^{120}$ For example, the test in $\mathrm{s} 15$ of the Equality Act 2010 makes it unlawful for a person to discriminate against another where it cannot be shown 'that the treatment is a proportionate means of achieving a legitimate aim'. Disability discrimination may be of such historical significance that any instance of it should face intense scrutiny. On its face this is a reasonable assertion and is an approach similar to that recognised by US courts, who define gender and race discrimination as 'suspect classifications' and therefore ought to be subject to 'strict scrutiny'. ${ }^{121}$ The difficulty with such an approach in the UK is that there is no basis for this distinction within the context of the Equality Act 2010. The Government's Explanatory Notes to s 15 state that the intention of the provision was to allow for the 'appropriate balance' between those facing discrimination and those that may have a legitimate aim resulting in discrimination. ${ }^{122}$ The same 'appropriate balance' is said to run through the package of rights in the HRA 1998, the overall goal of which is proportionality. ${ }^{123}$ Therefore, the argument that Parliament requires greater scrutiny of discrimination than of interferences with other fundamental rights does not hold weight.

The same comments made above are applicable to those instances where the common law protects fundamental rights, either those contained in the Convention or those which predate the HRA $1998{ }^{124}$ This is particularly timely given the renaissance in common law constitutionalism. ${ }^{125}$ Where the courts have considered common law fundamental rights, they have engaged with proportionality in all but name. ${ }^{126}$

The courts are clearly comfortable in applying the structure of full proportionality analysis where common law fundamental rights are concerned independent of the Convention and the HRA $1998 .{ }^{127}$ Therefore, whilst there are a range of options regarding the scrutiny to apply to interferences with common law fundamental rights, it seems rightly doubtful that the court would adopt any standard less than structured proportionality. The courts' blanket application of structured proportionality to

\footnotetext{
${ }^{117}$ A Tomkins Public Law (Oxford: Oxford University Press, 2003) p 3.

${ }^{118}$ HRA 1998, s 6.

${ }^{119} R v$ Secretary of State for Transport, ex p Factortame Ltd [1991] 1 AC 603.

${ }^{120} R$ (Ullah) $v$ Special Adjudicator [2004] UKHL 26, [2004] 2 AC 323 at [20]; $R$ (Al-Skeini) v Secretary of State for Defence [2007] UKHL 26, [2008] 1 AC 153 at [90]; Ambrose v Harris [2011] UKSC 43, [2011] 1 WLR 2435 at [126]-[130]; Lord Irvine of Lairg 'A British interpretation of convention rights' (UCL Judicial Institute, London, 14 December 2011); Smith v Ministry of Defence [2013] UKSC 41, [2014] AC 52.

${ }^{121}$ Baker, above n 74 .

${ }^{122}$ Equality Act 2010 Explanatory Notes at [69]-[70].

${ }^{123}$ Huang $v$ Secretary of State for the Home Department, above n 2; Bank Mellat, above n 3, at [70]-[72]; Gunn, above n 55, at 470 .

${ }^{124}$ Raymond $v$ Honey [1983] AC 1; $R v$ Secretary of State for the Home Department ex $p$ Brind [1991] 1 AC 696; $R v$ Secretary of State for the Home Department, ex $p$ Leech [1994] QB 198; $R v$ Secretary of State for the Home Department, ex p Simms \& O'Brian [1999] 3 WLR 328.

${ }^{125} \mathrm{M}$ Elliott 'Beyond the European Convention: human rights and the common law' (2015) 68 Current Legal Problems 85; P Bowen 'Does the renaissance of common law rights mean that the Human Rights Act 1998 is now unnecessary?' (2016) EHRLR 361.

${ }^{126}$ Elliott, above $\mathrm{n} 125$, at 102; $R v$ Secretary of State for the Home Department, ex p Leech [1994] QB 198; Daly, above n 71; $R$ (Mahmood) $v$ Secretary of State for the Home Department [2001] 1 WLR 840.

${ }^{127}$ Elliott, above n 125, at 103-104.
} 
common law fundamental rights makes it difficult to maintain the argument that there ought to be varying degrees of scrutiny for other fundamental rights. This is not to say that the trajectory of common law fundamental rights is settled. Bowen cites $R$ (Keyu) $v$ Secretary of State for Foreign and Commonwealth Affairs ${ }^{128}$ as an example of the uncertain structure of proportionality in the courts. ${ }^{129}$ However, the Supreme Court's rejection of proportionality in Keyu is very specific to the facts. The question before the court was not whether structured proportionality should be applied to potential infringements of fundamental rights, rather the question was whether proportionality ought to replace Wednesbury rationality review in relation to administrative acts. ${ }^{130}$ This is a very different proposition to the concern of this work, which is the use of full proportionality analysis where fundamental rights may have been interfered with. ${ }^{131}$

Whilst the normative backgrounds of each framework (EU, Convention, and common law) might give some cursory reason for the emergence of differing proportionality tests, they do not provide a contemporaneous justification for the differential tests themselves. In such circumstances there is the ever present danger of doctrinal confusion '... which is a recipe for inconsistency'. ${ }^{132}$

\section{In favour of uniform and replicable proportionality}

The aims of proportionality were explored by Lord Reed in his dissenting opinion in Bank Mellat. ${ }^{133}$ In this judgment Lord Reed unknowingly makes the argument for 'full proportionality analysis' as outlined above in section 3. In his judgment there are implicit suggestions which support this. The first is the acceptance that proportionality arises from a pursuit of 'fair balance' between the interests of the individual and the community at large. ${ }^{134}$ This idea cuts to the core of the common law's search for a 'just distribution of power'. ${ }^{135}$ Full proportionality analysis complements domestic jurisprudence advocating 'structured and stringent ${ }^{136}$ review of measures infringing rights. ${ }^{137}$ It is this structure of proportionality which forces judges to work through their findings in a transparent fashion. ${ }^{138}$ These attributes are visible in Bank Mellat, with the precise points of disagreement between the majority and minority of the Supreme Court clearly articulated. ${ }^{139}$

The second implicit recognition in Lord Reed's judgment is the 'broad-brush' approach of the European Court of Human Rights. ${ }^{140}$ It should be recalled that the European Court is not a court of precedent: it is not bound to follow its previous decisions and so does not approach matters in the same principled fashion a common law court might. ${ }^{141}$ Moreover, the European Court must concern itself with the margin of appreciation which seeks to afford Member States latitude to respect the

\footnotetext{
${ }^{128} R$ (Keyu) $v$ Secretary of State for Foreign and Commonwealth Affairs [2015] UKSC 69, [2015] 3 WLR 1665.

${ }^{129}$ Bowen, above n 125 , at 372 .

${ }^{130} \mathrm{Keyu}$, above n 128, at [131]-[140], [271]-[284].

${ }^{131}$ This distinction is noted by Lord Reed, Pham, above $\mathrm{n} 24$, at [113].

${ }^{132}$ Bjorge and Williams, above n 8 , at 188 .

${ }^{133}$ Bank Mellat, above n 3, at [70]-[72].

${ }^{134}$ JA Pye (Oxford) Ltd $v$ United Kingdom Application No 44302/02, Merits and Just Satisfaction, 30 August 2007 at [53]; Goodwin v United Kingdom Application No 28957/95, Merits, 11 July 2002 at para 72; Beyeler $v$ Italy Application No 33202/96, Merits, 5 January 2000.

${ }^{135}$ J Laws 'Public law and employment law: abuse of power' (1997) PL 455 at 455. See also J Laws 'The good constitution' (2012) 71 Cambridge Law Journal 567; P Scott 'On “domestic” law and the law of human rights: Osborn v the Parole Board' (2015) 25 King's Law Journal 147.

${ }^{136}$ Chan, above n 66 , at 6.

${ }^{137}$ Daly, above n 71; Huang $v$ Secretary of State for the Home Department, above n 2; R (Naik) $v$ Secretary of State for the Home Department [2011] EWCA Civ 1546, [2012] Imm AR 381.

${ }^{138}$ Davies and Williams, above n $29, \mathrm{p} 83$.

${ }^{139}$ Ibid.

${ }^{140} \mathrm{~S}$ Greer 'Constitutionalising adjudication under the European Convention on Human Rights' (2003) 23 Oxford Journal of Legal Studies 405 at $407-408$.

${ }^{141}$ A Mowbray 'An examination of the European Court of Human Rights' approach to overruling its previous case-law' (2009) 9 Human Rights Law Review 179.
} 
Convention, albeit within the context of their cultural and historical traditions. ${ }^{142}$ This is not to say that the domestic courts may not go further as they have done in developing structured proportionality. ${ }^{143}$ This is especially the case in the unique constitutional settlement of the UK in which it may be argued that it is the duty of the UK judiciary to develop a 'municipal law of human rights'. ${ }^{144}$ This is precisely what ought to happen in the case of proportionality in the UK. For example the proportionality assessment used in Akerman has been utilised in domestic cases concerning human rights arguments, in keeping with the analytical approach of the common law. ${ }^{145}$ In Akerman the Supreme Court found that this approach had been given a statutory footing in the Equality Act 2010, yet this stood apart from the proportionality assessment to be made where Art 8 was in play. These tests are clearly not two branches of the same tree on an equal footing.

Disparate proportionality analyses give rise to substantive theoretical issues. The first of these is an apparent pre-weighing of rights which is not present in the Convention or the HRA $1998 .{ }^{146}$ The second is the variable intensity of review based upon a right's legislative source. ${ }^{147}$ Thirdly, flexible unstructured proportionality tests unduly calibrate proceedings in the state's favour, essentially providing a general pre-emptive deference to state institutions. There is an element of reciprocal causality with these doctrines. The argument made here is not that the differential approaches which have been highlighted give rise to these phenomena, but rather they entrench and propagate these doctrines. Where the courts opt for flexible unstructured proportionality policy preferences become more pronounced, thereby making it difficult for a litigant to argue that a measure is disproportionate. ${ }^{148}$ Alternatively where it is unclear which proportionality test the courts will apply, it is equally difficult to coherently argue that a measure is proportionate.

Weighting of rights and intensity of review are naturally linked as one will necessarily lead to the other. ${ }^{149}$ The rights contained in the Convention and the HRA 1998 ought to be viewed as a whole indivisible 'single package. ${ }^{150}$ It is true that the European Court often refers to certain rights such as those contained in Arts 2, 3, and 7 as some of 'the most fundamental values of a democratic society. ${ }^{151}$ However, this does not amount to these rights trumping others in all circumstances; rather this is something for the judiciary in a given case to factor into their analysis of proportionality at the balancing stage in light of the level of the interference with that right (and perhaps others). ${ }^{152}$ It is suggested here that the domestic courts ought to recognise that, whilst some rights may in the abstract be weightier than others, where precedence will fall is a product of balancing and weighting to be conducted by the bench in that particular case. Another issue flowing from the current confusion around the precise contours of proportionality is the intensity of review placed upon a measure becomes dependent upon the right's legal source.

\footnotetext{
${ }^{142}$ Handyside v United Kingdom Application No 5493/72, Merits and Just Satisfaction, 7 December 1976; Connors v United Kingdom Application No 66746/01, Merits and Just Satisfaction, 27 May 2004.

${ }^{143} \mathrm{~N}$ Ferreira 'The supreme court in a final push to go beyond Strasbourg' (2015) PL 367 at 373-374; M Gordon 'The UK's fundamental constitutional principle: why the UK parliament is still sovereign and why it still matters' (2015) 26 King's Law Journal 229; Chan, above n 66, at 3-4.

${ }^{144}$ Laws (2012), above n 125 , at 578-579.

${ }^{145}$ Bank Mellat, above n 3; Huang $v$ Secretary of State for the Home Department, above n 2; R (ProLife Alliance) $v$ BBC [2003] UKHL 23, [2004] 1 AC 185.

${ }^{146}$ Greer, above $\mathrm{n} 140$, at 429 .

${ }^{147}$ Akerman-Livingstone $v$ Aster Communities Ltd, above n 5, at [23]-[34]. See also A Tahvanainen 'Hierarchy of norms in international and human rights law' (2006) 24 Nordic Journal of Human Rights 191 at 198.

${ }^{148} \mathrm{R}$ Sulitzeanu-Kenan, M Kremnitzer and S Alon 'Facts, preferences, and doctrine: an empirical analysis of proportionality judgment' (2016) 50 Law and Society Review 348.

${ }^{149}$ P Craig 'Proportionality, rationality and review' (2010) New Zealand Law Review 265 at 288-289.

${ }^{150}$ Tahvanainen, above n 147, at 204-205.

${ }^{151}$ Mursic v Croatia (2017) 65 EHRR 1 at [96]; Timishev v Russia (2007) 44 EHRR 37 at [64].

${ }^{152} \mathrm{M}$ Klatt and M Meister The Constitutional Structure of Proportionality (Oxford: Oxford University Press, 2012) at $26-42$.
} 
At present where Art 8 arises in possession proceedings a county court judge is expected to test interference with that right against a nebulous criteria which she is told she is best placed to determine in a given case. ${ }^{153}$ This is in contrast to full proportionality analysis as advocated in Lumsdon. The current differential approach to proportionality and the application of flexible unstructured proportionality in general unduly attenuates matters in favour of the state. For example in Pinnock the Supreme Court merged 'all four stages of the [proportionality] enquiry into one general question of ... whether the measure [was] reasonable or permissible. ${ }^{154}$ Under such a test it is incredibly difficult for a claimant to argue that the actions of the state are disproportionate due the heavy presumption made in the state's favour. The proportionality test therefore becomes little more than traditional Wednesbury reasonableness, rather than a penetrating analysis of whether the state has disproportionately infringed an individual's rights. ${ }^{155}$ In such instances the court may feel that it is appropriate to defer to the institutional competence of a state body, such as a local authority and its assessment of how best to manage its own legal interests, which often correlate with those of the community at large. This is an unnecessary assumption: full proportionality analysis seeks to measure the costs of any rights infringement for both the rights-holder and society overall. ${ }^{156}$ Moreover, making assumptions as to institutional superiority, whilst perhaps expedient, undermines the obligation placed upon the state to demonstrate an evidential basis for its belief that it has acted proportionately. ${ }^{157}$

In Akerman and Lumsdon the Supreme Court has sought to compartmentalise various applications of proportionality based on the source of the rights in question. However, this underplays and to an extent misunderstands the method by which EU rights and HRA rights are given effect within English law. In the case of rights based in EU law, the European Communities Act 1972 is not itself the 'originating source of those rights'; ${ }^{158}$ rather the 1972 Act is a 'conduit pipe ${ }^{159}$ through which EU law may have direct effect. Whereas those rights contained in the HRA 1998, whilst influenced by the European Court of Human Rights, ${ }^{160}$ exist by virtue of their inclusion in the HRA 1998, Sch 1. The HRA rights' 'source is the statute, not the Convention'. ${ }^{161}$ Therefore, if a robust proportionality analysis ought to apply to either set of rights, it should be those fundamental rights on a domestic footing. This is especially the case as the courts are experienced in weighing and balancing competing interests under the guise of reasonableness that is akin to proportionality even in those cases not concerning fundamental rights. ${ }^{162}$

Finally, Lumsdon suggests where a Convention right is at issue the court ought to use full proportionality analysis. However, where EU legislation is in play flexibility should be favoured over structure. It seems that in each instance the problem faced by the courts is not a lack of belief in structured proportionality as such, but which party should bear the burden for (dis)proving the proportionality of the measure in question. The uncertainty created by the judiciary to date is indicative of worry and uncertainty ${ }^{163}$ as to the angle from which proportionality should be approached. The same uncertainty is challenging for litigants who ought to be 'cognisant of the legal consequences of their actions'. ${ }^{164}$ Reanalysing Pinnock, Akerman and Lumsdon with this in mind demonstrates that full proportionality analysis is possible in all cases concerning fundamental rights.

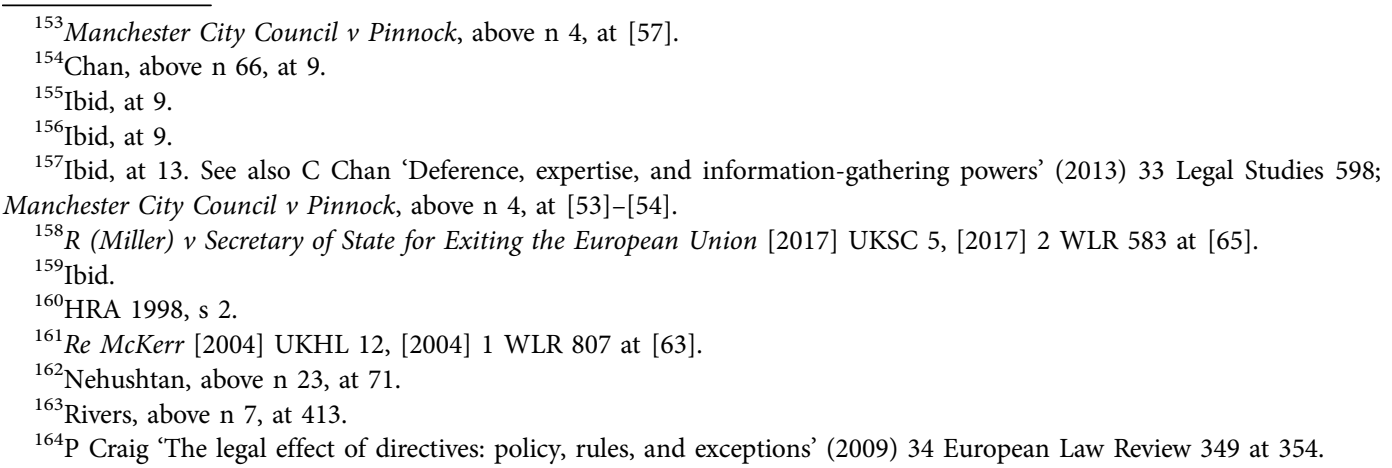


In assessing proportionality the courts regularly have trouble deciding where the burden of (dis)proving each of these questions will rest; should there be a 'presumption of proportionality' ${ }^{165}$ or should it be for the state to prove the proportionality of a measure? In Pinnock the Supreme Court clearly found that the presumption ought to be that the actions of a local authority were proportionate, whereas in Akerman the Supreme Court felt that ss 15 and 136 of the Equality Act 2010 required the infringing party to demonstrate the proportionality of the measure. ${ }^{166}$ This demonstrates the significance of the burden of proof when assessing proportionality. It is suggested here that the starting point for the court should be a shared burden of proof built into full proportionality analysis. Rivers' work is instructive on this point:

...[O]nce a state measure has crossed the rational threshold by being shown, by the state, to pursue a legitimate aim (stage 1 ) by means which are rationally connected to that aim (stage 2), the burden of proof shifts [from the defendant] to the claimant to demonstrate on the balance of probabilities either that an alternative measure is equally effective and less intrusive (stage 3), or that the measure is unbalanced in imposing an excessive cost to rights (stage 4). ${ }^{167}$

Rivers goes on highlight that there are cases where this bare allocation should be tweaked, thereby creating a presumption of proportionality requiring the right-holder to demonstrate disproportionality at all four stages. Foremost of such instances, for the purposes of this work, are those in which positive law proscribes a particular outcome ${ }^{168}$ and decisions made under proportionate sets of rules. ${ }^{169}$ The problem with Rivers' attenuation of the burden of proof in favour of the decision-maker in such cases is the fact insensitivity with which the courts would approach potential infringements of fundamental rights. ${ }^{170}$ Fact insensitive instruments or procedures are more likely to result in disproportionate interferences with fundamental rights. ${ }^{171}$ Therefore, any presumption of proportionality ought to be doubted to allow for a minimum standard of review in those cases where fundamental rights are at issue. ${ }^{172}$ Any presumption of proportionality by way of placing the burden of proof entirely on the shoulders of the right-holder is an abdication of the responsibilities placed on the judiciary by the HRA 1998. ${ }^{173}$ This is not to say that, as suggested by Chan, the burden of proof should be placed solely on the state. ${ }^{174}$ Such an approach would undermine the correlative adjudicative function of the court. ${ }^{175}$ It is the court that is best placed to assess the proportionality of an act due to its inherent experience in adversarial adjudication. ${ }^{176}$ Therefore, the court is concurrently the guardian of rights and the forum in which the parties will argue the proportionality of a measure. ${ }^{177}$ This requires a middle ground between holding the right-holder to the burden of proof ${ }^{178}$ and requiring the state to

\footnotetext{
${ }^{165}$ Rivers, above $n 7$.

${ }^{166}$ This is discussed in further detail below in section $7 \mathrm{~b}$.

${ }^{167}$ Rivers, above n 7 , at 427 .

${ }^{168}$ Ibid, at 428 .

${ }^{169}$ Ibid, at $429-430$.

${ }^{170}$ For a discussion of fact insensitive laws see P Sales and B Hooper 'Proportionality and the form of law' (2003) 119 LQR 426.

${ }^{171}$ Ibid, at $428-430$.

${ }^{172}$ See generally Chan, above n 66 , at 3 .

${ }^{173}$ HRA 1998, ss 2-6; International Transport Roth GmbH v Secretary of State for the Home Department [2002] EWCA Civ 158, [2003] QB 728 at [27]; Lord Steyn 'Deference: a tangled story' (2005) PL 346 at 351.

${ }^{174}$ Chan, above $\mathrm{n} 66$, at $7-8$.

${ }^{175}$ HRA 1998, s 6.

${ }^{176}$ Chan, above n 66; D Feldman 'Human rights, terrorism and risk: the roles of politicians and judges' (2006) PL 364; T Hickman 'Constitutional dialogue, constitutional theories and the Human Rights Act 1998' (2005) PL 306.

${ }^{177}$ Lady Hale 'The supreme court: guardian of the constitution?' (Sultan Azlan Shah Lecture, Kuala Lumpur, 9 November 2016).

${ }^{178}$ Rivers, above n 7.
} 
demonstrate proportionality. ${ }^{179}$ Rivers' bare placement of the burden of proof provides a model for the court to balance the competing interests of parties engaged in rights adjudication. Concurrently this provides the 'argumentative structure ${ }^{\text {'180 }}$ which proportionality requires, thereby making clear to courts and litigants the requirements of full proportionality analysis.

In earlier work Rivers discusses other considerations which may colour the intensity of review arising from proportionality. ${ }^{181}$ For Rivers, deference or restraint may allow for the courts to vary the intensity of review applied when asking if a measure is proportionate. However, as discussed above, it is deference that has resulted in several conceptions of proportionality being simultaneously applied by the courts. In considering the 'relative institutional competence' ${ }^{182}$ the court should recall its adjudicative function in addition to its institutional relationship with other state bodies. When asking an infringing party to argue that a measure pursues a legitimate aim and that the measure has a rational connection to that aim (stages 1 and 2 of full proportionality analysis) the court ought not to accept that the body's 'assessment is sufficiently reliable'183 unless that body has sufficiently demonstrated to the court, following arguments from the rights-bearer, that the measure indeed pursues a legitimate aim and has a rational connection. To vary the intensity of review with respect to deference would allow for the structure of full proportionality analysis to apply but the variability in its application would still be visible. If the infringing party has greater institutional expertise than the court to make decisions which may infringe fundamental rights, then it is difficult to imagine where demonstrating legitimacy and rationality would be challenging. Following this, Rivers' assertion that the greater the interference with a fundamental right, 'the more evidence the court will require that the factual basis of the limitation has been correctly established', ${ }^{184}$ does not hold. This approach would alter the question asked by the courts from one of legitimate aim and rational connection to one of whether there is sufficient evidence to support the assertion that the measure was proportionate. Such a view would logically lead to an acceptance that some fundamental rights are more important than others, not only in the abstract sense, but also on the facts before the court. ${ }^{185}$ The problems flowing from an a priori hierarchy of rights have been highlighted above and have played a part in the disparate approaches to proportionality in the courts to date. For this reason, the variable intensity of review suggested by Rivers is rejected. However, the suggestion that parties ought to provide as detailed and weighty evidence as possible in arguing for (dis)proportionality is very much at the core of what is required of parties under full proportionality analysis. This is not a reallocation of the bare placement of the burden of proof: rather this is an aid for litigants who wish to argue for (dis)proportionality. With a rejection of deference under full proportionality analysis, an 'institutionally sensitive ${ }^{186}$ approach is equally unwelcome due to the disparate conceptions of proportionality and related shortcomings identified in the earlier parts of this paper.

Having full proportionality analysis be the court's starting point for any assessment of proportionality ensures that litigants' minds are focused on the requirements of proportionality and precisely which limbs of the proportionality test must be satisfied. The benefits of this starting point are evident when considered alongside the cases discussed below.

\footnotetext{
${ }^{179}$ Chan, above $\mathrm{n} 66$.

${ }^{180}$ Rivers, above n 7, at 409; M Kumm 'Constitutional rights as principles: on the structure and domain of constitutional justice’ (2004) 2 International Journal of Constitutional Law 574 at 579; A Stone-Sweet and J Matthews 'Proportionality balancing and global constitutionalism' (2008-09) 47 Columbia Journal of Transnational Law 72 at 75-90.

${ }^{181}$ Rivers, above n 31 .

${ }^{182} \mathrm{Ibid}$, at 203.

${ }^{183} \mathrm{Ibid}$, at 204 .

${ }^{184} \mathrm{Ibid}$, at 205.

${ }^{185}$ Ibid, at $205-206$.

${ }^{186}$ ADP Brady Proportionality and Deference under the UK Human Rights Act (Cambridge: Cambridge University Press, 2012).
} 


\section{Full proportionality analysis applied}

The following passages owe much to the work of $\mathrm{Chan}^{187}$ and Rivers ${ }^{188}$ in extrapolating the character of proportionality. The three conflicting approaches discussed above have each touched upon what may be called 'rules and exceptions', ${ }^{189}$ ie rights which may be derogated from in prescribed circumstances, making the model of proportionality applied particularly important. The following discussion will apply full proportionality analysis to three of the cases highlighted above: Pinnock, Akerman, and Lumsdon.

\section{(a) Manchester City Council v Pinnock}

Mr Pinnock argued that a possession order was disproportionate and therefore a breach of Art 8. Nevertheless the court found an order to be a proportionate means of achieving a legitimate aim. Applying full proportionality analysis to Pinnock would have directed the court's attention to the substantive interests in play which are largely ignored by flexible unstructured proportionality. In applying full proportionality analysis the court must first ask whether the local authority's objective is sufficiently important to justify limiting a fundamental right. The local authority's objective in Pinnock was recovery of property in pursuit of its statutory duties. ${ }^{190}$ This objective matches the qualifications in Art 8(2) of the Convention, thereby satisfying the first stage of structured proportionality.

Second, 'is the measure rationally connected to the objective?' Like the first stage, it is straightforward to argue that the means used by the local authority are rationally connected to its aim. It is difficult to think of other means which might be used to recover possession of the property in this case. ${ }^{191}$ This clearly 'makes some contribution to the aim'192 pursued by the authority.

Third, the state must prove that the measure is 'no more than necessary to accomplish the objective. ${ }^{193}$ It is here that the courts are likely to face the most difficulty in assessing the proportionality of a possession order. In Pinnock the local authority's objective was the recovery of possession in pursuit of the removal of Mr Pinnock's family, who had been the source of anti-social behaviour. On this basis it seems in the least arguable that removing Mr Pinnock from his home in order to remove his family and their anti-social behaviour is more than necessary to accomplish the council's objective. If the local authority is unsuccessful on this head then the measure will be disproportionate and therefore fail. ${ }^{194}$ The question then becomes what other powers a local authority possesses to achieve its aim. In 2010 when Pinnock reached the Supreme Court Anti-Social Behaviour Orders (ASBO) were extant, therefore Mr Pinnock logically argued that the correct course for the Supreme Court would be ASBOs or similar orders, ${ }^{195}$ excluding Mr Pinnock's children from the area and thereby eliminating the opportunity for further anti-social behaviour. ${ }^{196}$ The court considered this, but reached the view that such an order would not quell the anti-social behaviour as they had failed in the past. ${ }^{197}$ Bearing in mind the criminal liability which flows from the breach of an ASBO or similar order, it is difficult to follow the court's reasoning when the problem is reassessed through the lens of whether the measure was 'no more than necessary to accomplish the objective' sought. If the possibility of

\footnotetext{
${ }^{187}$ Chan, above n 66.

${ }^{188}$ Rivers, above $\mathrm{n} 7$.

${ }^{189}$ Ibid, at 421 .

${ }^{190}$ Manchester City Council v Pinnock, above n 4, at [52].

${ }^{191}$ However, there are instances where it may be arguable that the means used to recover possession of another's home are not rationally connected to that objective. For instance see McDonald $v$ McDonald, above n 52; S Nield 'Thumbs down to the horizontal effect of article 8' (2015) Conv 77 at 80-81.

${ }^{192}$ Rivers, above $\mathrm{n} 7$, at 421 .

${ }^{193}$ Ibid, at 422 .

${ }^{194}$ Ibid, at 414 .

${ }^{195}$ Crime and Disorder Act 1998, s 1; Housing Act 1996, s 153 C.

${ }^{196}$ Manchester City Council v Pinnock, above n 4, at [124].

${ }^{197}$ Ibid, at [125]-[130].
} 
criminal liability was not able to dissuade Mr Pinnock's children from anti-social behaviour, why should Mr Pinnock bear responsibility for their actions. In such a case the measure seems to be more than necessary to achieve its aim.

Fourth, the balancing exercise: it was accepted by the court that granting possession to the local authority would amount to a prima facie breach of Art 8(1). However, a possession order would serve to protect the interests of the local community. Balancing rights requires gains to community interests to be 'at least as great as the cost to rights'. ${ }^{198}$ Proving this will turn on a claimant's ability to demonstrate that the measure is 'out of line with the order of values expressed more widely in the law and public culture. ${ }^{199}$ In this case it seems difficult for Mr Pinnock to argue that his Art 8 rights ought to outweigh the Art 8 rights of neighbouring tenants who suffered due to his family's anti-social behaviour and so there does not seem to be 'an excessive cost to rights'. ${ }^{200}$

Applying full proportionality analysis to Pinnock has demonstrated that the courts have erred in seeking to maintain flexible proportionality due to the judicial confusion and uncertainty that has followed. ${ }^{201}$ In looking to afford deference to local authorities, the courts have undermined 'the clear and rational structure of the proportionality test itself. ${ }^{202}$ Full proportionality analysis allows for the courts to insightfully test the acts of public authorities against the requirements of fundamental rights with a view to minimising the extent to which human rights are infringed. In Pinnock the Supreme Court displayed a remarkable deference to the local authority. ${ }^{203}$ Full proportionality analysis shifts focus from the institutional nature of the decision making body and places the burden upon the rights-holder and the public authority to demonstrate that a measure is (dis)proportionate.

\section{(b) Akerman-Livingstone $v$ Aster Communities Ltd}

The Equality Act 2010 states that where there has been unfavourable treatment of someone due to a prescribed characteristic, it will be discriminatory unless treatment is 'a proportionate means of achieving a legitimate aim'. ${ }^{204}$ In such instances it will be for the 'alleged discriminator' to prove that there were no discriminatory acts. ${ }^{205}$ On this formulation it appears that Parliament has streamlined the proportionality analysis. However, if one looks more closely there is no reason why this could not be applied in much the same way as full proportionality analysis with four stages and the bare allocation of burdens identified above. The very existence of $s 15$ focuses the court's mind on the question of whether an objective is sufficiently important to justify discriminatory behaviour. The words 'legitimate aim' in s 15 require the court to consider whether the behaviour is rationally connected to the purported objective, whilst the proportionality of the means used requires the act to be no more than necessary to achieve the objective in light of the discrimination suffered. Therefore, the only streamlining in $\mathrm{s} 15$ is one of syntax rather than substance.

Taking the above view as to the application of proportionality casts the facts of the case in a new light, which is thoughtfully explored by Lord Wilson. For Lord Wilson, '[ $t$ ] he structured approach requires attention to be given, first, to the claimant's aims or objectives in taking the steps for the purpose of securing the defendant's eviction'. ${ }^{206}$ Whilst Lord Wilson expresses the first step of proportionality differently to that outlined above, it is substantively the same enquiry, with the outcome

\footnotetext{
${ }^{198}$ Rivers, above $n$ 7, at 426 .

${ }^{199}$ Ibid, at 427 .

${ }^{200}$ Ibid.

${ }^{201}$ Thurrock $v$ West, above n 52; Southend-on-Sea BC v Armour [2014] EWCA Civ 231, [2014] HLR 23; McDonald v McDonald, above n 52.

${ }^{202}$ Rivers, above n 7 , at 432 .

${ }^{203}$ As to the nature of deference in such cases see C Hunter and D Cowan "'Yeah but, no but" - Pinnock and Powell in the Supreme Court' (2012) 75 MLR 78.

${ }^{204}$ Equality Act 2010, s 15(1)(b).

${ }^{205}$ Akerman-Livingstone $v$ Aster Communities Ltd, above $\mathrm{n}$ 5, at [19].

${ }^{206}$ Ibid, at [68].
} 
remaining the acceptance of the local authority's argument that the eviction was sought in pursuit of its own legal obligations to provide the flat to a new owner with vacant possession. ${ }^{207}$ Therefore, not only did the local authority no longer wish to house homeless tenants in that particular building, but the local authority no longer had the legal authority to award tenancies or allow tenancies to continue. ${ }^{208}$ Submissions to this effect were made by the authority throughout the proceedings, thereby fulfilling the burden of proof placed upon it by full proportionality analysis. Therefore, the authority has successfully demonstrated that its objective is sufficiently important to justify dispossessing the tenant.

In applying the second, third, and fourth step of a structured proportionality analysis Lord Wilson conflates the issues, albeit in reaching a sensible conclusion. Lord Wilson's approach on these issues is perhaps understandable, given their straightforward application. The objective of the local authority was vacant possession of the flat to enable the freeholder to exercise his absolute right to possession. Related to this the local authority had sought to fulfil its statutory obligation to house the tenant in the same street, which had been unsuccessful due to the tenant's refusal to take up the tenancy in light of his severe disability pending therapy. Clearly, the authority's actions are rationally connected to its objective - vacant possession. Further, it is difficult to conceive a less intrusive measure which would achieve the authority's objective given uncertainty around when the tenant may be well enough to take on a new tenancy. ${ }^{209}$ Therefore, the second and third heads of full proportionality analysis are fulfilled. On the final head of proportionality the question is whether the impact of the measure is disproportionate to the resultant benefits. It is here that the unique situation in the case is particularly acute. In circumstances where the local authority intended to house another homeless tenant in the flat then it would be difficult to think that the benefits of eviction would outweigh the difficulties faced by the tenant in finding alternative accommodation. However, the delay in providing the thirdparty freeholder of the building with vacant possession had led to the local authority being potentially liable to the freeholder for damages flowing from their inability to sell. In light of this and the uncertainty as to when the tenant may be able to move from the flat, it seems proportionate (and therefore not discriminatory) to evict the tenant despite the significant anguish this might cause.

The judgment in Akerman demonstrates two matters. First, the application of full proportionality analysis does not serve to irrevocably recalibrate proceedings in favour of the party arguing a contravention of their rights, such as that which appears to have unsettled the Supreme Court in Pinnock. Second, full proportionality analysis does not have to be limited to instances in which a person's Convention rights or EU law is at issue; rather, where any fundamental right is threatened, proportionality is able to serve as a general head of review and therefore courts ought to be confident in their application of proportionality.

\section{(c) $R$ (Lumsdon) v Legal Services Board}

Lord Reed and Lord Toulson's assessment of proportionality in Lumsdon contended that four-stage proportionality is not applicable in instances concerning EU law. This assertion flows from the risk in trying to identify 'general principles [of EU law]', ${ }^{210}$ thereby underplaying the nuances present in the CJEU's jurisprudence, which according to their Lordships conceptualises proportionality as a two-stage test concerning the suitability of a measure and its necessity. ${ }^{211}$ However, an examination of the CJEU's case law and the application of this test in Lumsdon demonstrate that courts are only nominally applying simplified proportionality, whilst four-stage proportionality is never far away. ${ }^{212}$

\footnotetext{
${ }^{207}$ Ibid, at [70].

${ }^{208}$ Ibid, at [72].

${ }^{209} \mathrm{Ibid}$, at [74].

${ }^{210}$ Lumsdon, above n 6, at [23].

${ }^{211}$ Ibid, at [33].

${ }^{212}$ See for example the search for balance in Case C-43/75 Defrenne $v$ SA Belge de Navigation Aerienne (SABENA) [1976] 2 CMLR 98.
} 
The two stages accepted by the Supreme Court in Lumsdon conflate the first three stages of full proportionality analysis. Thereafter, the court identifies a line of jurisprudence in the CJEU in which the balance of a measure will be assessed and the burden will be weighed against the purported advantages. ${ }^{213}$ The final point made in relation to the structure of proportionality in matters of EU law is the varying intensity applied by the CJEU. ${ }^{214}$ This is remarkably similar to the balancing task advocated by the fourth limb of full proportionality analysis, which requires a balance of the advantages of the measure versus the disadvantages. This assessment will of course be coloured by the 'values expressed more widely in the law and public culture'. ${ }^{215}$ The question therefore becomes why the Supreme Court in Lumsdon felt it necessary to distinguish between proportionality in Convention (and HRA 1998) cases and EU cases.

For Lord Reed the distinction was a result of the varying approaches of the CJEU and proportionality's application in particular instances. In the case of national measures derogating from 'fundamental freedoms', now consolidated in the EU Charter of Fundamental Rights, ${ }^{216}$ the court should, in the opinion of the Supreme Court, apply the following four-stage test:

1. the derogation must be applied in a non-discriminatory manner;

2. the aims of the measure must be sought in the general interest;

3. the measure must be suitable for securing the attainment of the objective; and

4. the measure must not go beyond what is necessary in order to attain it. $^{217}$

Stages 3 and 4 of this test 'correspond to the two limbs of the [CJEU] proportionality principle'. ${ }^{218}$ In all of the EU jurisprudence referred to in Lumsdon it appears that it is the institutional or legislative source of a measure which determines the scrutiny to be applied by the court. The shortcomings of varying levels of review have been explored in the realm of anti-discrimination law which, essentially employing proportionality, require the courts to come to terms with what are in effect value judgments in factually sensitive proceedings. ${ }^{219}$ This approach is clearly similar to that recognised by Lord Reed in Lumsdon, in which the severity of review will depend upon the institutional source of the measure in question.

The key argument in favour of differential scrutiny suggests that the practice may insulate judges from value judgments or judicial discretion. ${ }^{220}$ The related shortcoming of attributing differential scrutiny to measures dependent upon the right in issue is the covert creation of a priori weighting not present in their originating instruments. This is particularly the case in those instances where rights may clash with one another. Moreover, the purported insulation provided by variable scrutiny is an illusion that requires the judiciary to adopt their own value analysis as to what is the more important legislative source for the rights in issue, in effect balancing rights. ${ }^{221}$ This is concerning in terms of legal certainty, as it forces the court to balance rights behind a veneer of objectivity in matters which are at their core subjective. ${ }^{222}$ In such cases it would therefore be appropriate for the courts

\footnotetext{
${ }^{213}$ Lumsdon, above n 6, at [33]. See also Case C-62/14 Gauweiler v Deutsche Bundestag [2016] 1 CMLR 1, in particular the opinion of AG Cruz Villalón.

${ }^{214}$ Lumsdon, above n 6, at [34].

${ }^{215}$ Rivers, above $\mathrm{n} 7$, at 427.

${ }^{216}$ Case C-617/10 Aklagaren v Åkerberg Fransson [2013] 2 CMLR 46 at 1286.

${ }^{217}$ Case C-55/94 Gebhard v Consiglio dell'Ordine degli Avvocati e Procuratori di Milano [1996] 1 CMLR 603 at [37]; Lumsdon, above n 6, at [52].

${ }^{218}$ Lumsdon, above n 6, at [53].

${ }^{219}$ Baker, above n 74; J Small 'Structure and substance: developing a practical and effective prohibition on discrimination under the European Convention on Human Rights' (2003) 6 International Journal of Discrimination and the Law 45; I Joory 'Arguments against the politicised role of comparators in article 14 discrimination cases' (2009) 5 Cambridge Student Law Review 40.

${ }^{220}$ Baker, above n 74 , at 877 .

${ }^{221}$ Ibid, at 878 .

${ }^{222}$ Lord Justice Stanley Burnton 'Proportionality' (2011) 16 Judicial Review 179 at 181.
} 
to make clear their reasoning by adopting full proportionality analysis. This would not require a break from Lumsdon as such, but would serve to allow the court's guidance on the jurisprudence of the CJEU to 'calibrate proportionality in the light of prior value determinations'. ${ }^{223}$ This calibration would take place in the fourth test stage of the proportionality analysis recognised in Bank Mellat, which also features in the jurisprudence of the CJEU as influenced by the European Court of Human Rights. ${ }^{224}$ It will be recalled that the fourth stage of full proportionality analysis is 'whether the impact of the rights infringement is disproportionate to the likely benefit of the impugned measure'. ${ }^{225}$ In the High Court hearing of Lumsdon this is precisely the test that Sir Brian Leveson applied. In reviewing the 'fair balance' 226 of the scheme, Sir Brian noted the importance of good quality advocacy to the effective operation of the criminal justice system which is a benefit to the community as a whole, recognising that the pursuit for fair balance should not be conducted in a vacuum. ${ }^{227}$ This realisation allows for the High Court's finding that the measure is not disproportionate and therefore not in breach of EU legislation. This is not a different outcome to that of the Supreme Court upon the same facts, but rather a principled judgment with the benefit of 'a powerful... predictive tool', ${ }^{228}$ thereby providing precedential value for future litigation and, in particular, non-judicial parties who are tasked with ensuring their actions are proportionate. In light of this it seems apt that the Supreme Court reneges from its uncompromising judgment in Akerman and embraces the advantages of full proportionality analysis in all cases concerning fundamental rights.

\section{Conclusion}

The current inconsistent jurisprudence around the role of proportionality in domestic proceedings is highly problematic. The Supreme Court perhaps deserves sympathy for its attempts to cast proportionality in guises that it feels are appropriate for the enormous range of circumstances in which the proportionality of a measure may be questioned. Pinnock, Akerman, and Lumsdon offer a small overview of the factual matrices which the courts regularly face. In developing various models for proportionality the Supreme Court has overlooked the fact that much of the doctrinal groundwork for developing a standard proportionality exercise is already complete and present in full proportionality analysis. Full proportionality analysis may go further than the HRA 1998, the European Court of Human Rights and even the CJEU require, but that should not take away from the central task of the court in such cases: the protection of fundamental rights. ${ }^{229}$ Furthermore, in developing multiple approaches to proportionality the Supreme Court has unwittingly created a situation in which the intensity with which an infringement will be tested is dependent upon matters outside of a rights-holder's control, for example the legislative source of a right or the institutional character of the guilty party. The shortcomings of differential proportionality tests are starker again following the application of full proportionality analysis to existing case law. The Supreme Court should adopt full proportionality analysis and thereby grasp the nettle created by the current doctrinal confusion.

\footnotetext{
${ }^{223}$ Baker, above n 74 , at 882 .

${ }^{224}$ Case C-28/08P Commission of the European Communities $v$ The Bavarian Lager Co Ltd [2011] Bus LR 867 at para 95; Case C-141/12 YS v Minister voor Immigratie [2015] 1 WLR 609; Case C-212/13 Ryneš v Úřad pro ochranu osobních údaju [2015] 1 WLR 2607.

${ }^{225}$ Bank Mellat, above n 3, at [74].

${ }^{226} R$ (Lumsdon) v Legal Services Board [2014] EWHC 28 (Admin) at [130].

${ }^{227}$ Ibid, at para 1; L Hoyano 'What is balanced on the scales of justice? In search of the essence of the right to a fair trial' (2014) Crim LR 4 at 4.

${ }^{228}$ Hickman, above n 34 , at 716.

${ }^{229}$ International Transport Roth GmbH $v$ Secretary of State for the Home Department [2002] EWCA Civ 158, [2003] QB 728 at [27]; Baroness Hale 'Who guards the guardians' (2014) 3 Cambridge Journal of International and Comparative Law 100; T Etherton 'Liberty, the archetype and diversity: a philosophy of judging' (2010) PL 727.
} 